\title{
HUBUNGAN PENDAPATAN ASLI DAERAH (PAD) DAN \\ DANA ALOKASI UMUM (DAU) DENGAN BELANJA MODAL PADA KABUPATEN/KOTA DI JAWA BARAT
}

\author{
Oleh : \\ Ikin Solikin \\ (Dosen Program Studi Akuntansi Fakultas Pendidikan Ekonomi \& Bisnis UPI BHMN Bandung) \\ Widiawaty \\ (Alumni Program Studi Akuntansi Fakultas Pendidikan Ekonomi \& Bisnis UPI BHMN Bandung)
}

\begin{abstract}
Abstrak
Belanja modal dilakukan oleh Pemerintah Daerah (Pemda) untuk pengadaan asset daerah sebagai investasi, dalam rangka pelaksanaan otonomi daerah yang pada akhirnya bertujuan untuk meningkatkan kesejahteraan masyarakat. Akan tetapi hal ini belum terpenuhi seutuhnya apabila melihat pada besarnya alokasi belanja modal yang belum terlalu tinggi dibandingkan dengan belanja lainnya, padahal semakin banyak belanja modal maka semakin tinggi pula produktivitas perekonomian. Hasil penelitian menggunakan korelasi product moment pearson dan korelasi berganda menunjukkan bahwa PAD dan DAU memiliki hubungan positif yang kuat dengan belanja modal. Hal ini berarti semakin tinggi PAD atau DAU yang diterima maka semakin tinggi pula belanja modal yang dikeluarkan
\end{abstract}

Kata Kunci: Pendapatan Asli Daerah (PAD), Dana Alokasi

Umum (DAU), Belanja Modal, Keuangan Daerah

\section{Latar Belakang Penelitian}

Belanja modal sebagai bentuk perubahan yang cukup fundamental di dalam Anggaran Pendapatan dan Belanja Daerah (APBD) telah mulai dilakukan pasca reformasi dengan didasarkan pada peraturan-peraturan mengenai otonomi daerah terutama UU No 22/1999, UU No 25/1999, PP No $105 / 2000$, dan PP No $108 / 2000$ (Halim, 2002:18). Sebelumnya di dalam APBD, pengalokasian untuk jenis belanja berupa investasi, diklasifikasikan kedalam belanja pembangunan. Layaknya belanja pembangunan, belanja modal dilakukan oleh Pemerintah Daerah (Pemda) untuk pengadaan asset daerah sebagai investasi, dalam rangka membiayai pelaksanaan otonomi daerah yang pada akhirnya bertujuan untuk meningkatkan kesejahteraan masyarakat.

Armayani (dalam Halim, 2004:237) menyatakan bahwa peran pemerintah di dalam pembangunan adalah sebagai katalisator dan fasilitator, karena pihak pemerintahlah yang lebih mengetahui sasaran tujuan pembangunan yang akan dicapai. Sebagai pihak katalisator dan fasilitator maka pemerintah daerah memerlukan sarana dan fasilitas pendukung yang direalisasikan melalui belanja modal guna meningkatkan pelayanan publik. 
Tabel berikut menunjukkan mengenai belanja modal secara garis besar Pemda Kabupaten dan Kota di Jawa Barat pada tahun 2007:

Gambaran belanja modal pada Kab/Kota di Jawa Barat Tahun Anggaran 2007 (dalam Rupiah)

\begin{tabular}{|c|c|c|c|c|}
\hline NO. & КАВКОТА & BELANJA MODAL & TOTAL BELANJA & $\begin{array}{c}\text { PERSENTASE } \\
\text { B.MODALTOTAL } \\
\text { BELANJA }\end{array}$ \\
\hline 1 & KAB. BANDUNG & $370,894,040,025.00$ & $1,799,975,720,460.00$ & 20.61 \\
\hline 2 & KAB. BEKASI & $416,359,175,178.00$ & $1,140,876,442,354,00$ & 36.49 \\
\hline 3 & KAB. BOGOR & $340,917,888,624.35$ & $1,482,581,303,792.92$ & 22.99 \\
\hline 4 & KAB. CIAMIS & $308,616,187,054.00$ & $1,153,075,330,415.00$ & 26.76 \\
\hline 5 & KAB. CIANJUR & $202,577,544,897.00$ & $1,051,040,069,921.00$ & 19.27 \\
\hline 6 & KAB. CIREBON & $158,254,782,345.00$ & $1,009,398,560,833.00$ & 15.68 \\
\hline 7 & KAB. GARUT & $218,555,522,123.00$ & $1,133,154,783,047.83$ & 19.29 \\
\hline 8 & KAB. INDRAMAYU & $217,127,227,268.00$ & $949,785,078,309.00$ & 22.86 \\
\hline 9 & KAB. KARAWANG & $194,034,786,184.00$ & $1,052,226,593,083.00$ & 18.44 \\
\hline 10 & KAB. KUNINGAN & $111,643,588,006.00$ & $744,820,418,217.14$ & 14.99 \\
\hline 11 & KAB. MAJALENGKA & $201,555,244,177.00$ & $808,033,721,367.00$ & 24.94 \\
\hline 12 & KAB. PURWAKARTA & $78,309,819,378.00$ & $570,061,280,567.00$ & 13.74 \\
\hline 13 & KAB. SUBANG & $193,916,992,045.00$ & $894,949,537,972.18$ & 21.67 \\
\hline 14 & KAB. SUKABUMI & $188,217,807,009.00$ & $1,062,715,047,125.56$ & 17.71 \\
\hline 15 & KAB. SUMEDANG & $99,994,029,492.00$ & $782,010,631,360.00$ & 12.79 \\
\hline 16 & KAB. TASIKMALAYA & $227,324,556,866.00$ & $939,716,887,681.00$ & 24.19 \\
\hline 17 & KOTA BANDUNG & $232,007,682,250.00$ & $1,552,886,614,168.00$ & 14.94 \\
\hline 18 & KOTA BANJAR & $152,937,178,989.00$ & $351,790,973,500.00$ & 43.47 \\
\hline 19 & KOTA BEKASI & $308,046,563,959.00$ & $1,028,289,186,131.00$ & 29.96 \\
\hline 20 & KOTA BOGOR & $113,016,105,004.00$ & $582,735,392,917.00$ & 19.39 \\
\hline 21 & KOTA CIMAHI & $100,877,999,547.00$ & $439,563,980,694.80$ & 22.95 \\
\hline 22 & KOTA CIREBON & $90,168,311,282.00$ & $495,436,497,473.00$ & 18.20 \\
\hline 23 & KOTA DEPOK & $170,022,939,551.20$ & $749,181,867,085.65$ & 23.64 \\
\hline 24 & KOTA SUKABUMI & $68,837,294,096.00$ & $395,611,802,023.00$ & 17.40 \\
\hline 25 & KOTA TASIKMALAYA & $105,770,333,865.00$ & $534,863,201,674.17$ & 19.78 \\
\hline & Rata-Rata & $194,799,343,968.58$ & $906,991,236,886.89$ & 21.69 \\
\hline
\end{tabular}

Sumber: Hasil audit BPK (data diolah)

Pada tabel tersebut dapat dilihat bagaimana gambaran belanja modal pada pada $25 \mathrm{Kab} / \mathrm{Kota}$ di Jawa Barat tahun 2007. Rata-rata belanja modal adalah 21,69\% dari keseluruhan belanja daerah, dengan rincian 10 pemda telah melakukan belanja modal diatas rata-rata dan sisanya yaitu 15 pemda yang melakukan belanja modal dibawah rata-rata.

Sebenarnya tidak ada ukuran yang mengharuskan besarnya belanja modal. Alokasi belanja modal disesuaikan dengan kebutuhan daerah akan sarana dan prasarana baik untuk kelancaran tugas pemerintahan maupun untuk fasilitas publik (Halim dan Abdullah, 2006:19). Apalagi menurut Halim (2002:72) bahwa dengan melakukan belanja modal akan menimbulkan konsekuensi berupa penambahan biaya yang bersifat rutin seperti biaya pemeliharaan. Akan tetapi melihat keadaan tersebut juga dapat menimbulkan indikasi bahwa Pemda lebih banyak mengalokasikan belanjanya pada 
sektor-sektor yang kurang diperlukan dan lebih banyak digunakan untuk belanja rutin yang kurang produktif dibandingkan untuk meningkatkan pelayanan publik, sebab dari $100 \%$ belanja daerah rata-rata hanya $21,69 \%$ yang digunakan untuk belanja modal untuk pengadaan asset sebagai investasi dalam rangka meningkatkan pelayanan publik.

Berkaitan dengan pelayanan publik, alokasi belanja modal merupakan hal - yang sangat penting untuk diperhatikan karena akan meningkatkan produktivitas perekonomian daerah. Semakin banyak belanja modal maka semakin tinggi pula produktivitas perekonomian karena belanja modal berupa infrastruktur jelas berdampak pada pertumbuhan ekonomi dan penciptaan lapangan kerja (Media Indonesia, 2008). Senada dengan hal tersebut Hariyanto dan Hari Adi (2006) menjelaskan bahwa tersedianya infrastruktur yang baik diharapkan dapat menciptakan efisiensi dan efektifitas di berbagai sektor, produktifitas masyarakat diharapkan semakin tinggi dan pada gilirannya terjadi peningkatan pertumbuhan ekonomi.

Akan tetapi dengan melihat fenomena yang terjadi, sepertinya alokasi belanja modal belum sepenuhnya dapat terlaksana bagi pemenuhan kesejahteraan publik, sebab pengelolaan belanja daerah terutama belanja modal masih belum terorientasi pada publik. Salah satunya disebabkan oleh pengelolaan belanja yang terbentur dengan kepentingan golongan semata. Keefer dan Khemani (dalam Halim dan Abdullah, 2006:18) menyatakan bahwa adanya kepentingan politik dari lembaga legislatif yang terlibat dalam proses penyusunan anggaran menyebabkan alokasi belanja modal terdistorsi dan sering tidak efektif dalam memecahkan masalah di masyarakat. Padahal menurut Pasal 66 UU No. 33 Tahun 2004 menyatakan bahwa: "Keuangan daerah dikelola secara tertib, taat pada peraturan perundang-undangan, efisien, ekonomis, efektif, transparan, dan bertanggung jawab dengan memperhatikan keadilan, kepatuhan, dan manfaat untuk masyarakat". UU tersebut mengisyaratkan kepada Pemda untuk mengelola keuangan daerah terutama belanja modal secara efektif, efisien, dan ekonomis dengan tujuan akhir untuk meningkatkan pelayanan masyarakat.

Akan lebih baik jika alokasi belanja pemda di daerah lebih banyak digunakan untuk belanja modal yang berorientasi publik, sebab sejak krisis ekonomi melanda Indonesia pada tahun 1997 telah menyebabkan terjadinya penurunan kapasitas fiskal daerah yang berdampak pada semakin meningkatnya kesenjangan fiskal yang dihadapi daerah (Mardismo, 2002:167), dan diharapkan dengan adanya peningkatan alokasi belanja modal maka akan menstimulasi perekonomian melalui kegiatan perekonomian yang produktif, yang nantinya akan berimplikasi pada peningkatan penerimaan daerah sehingga kapasitas fiskal dapat meningkat kembali dan kesenjangan fiskal dapat diminimalisir.

Stine (dalam Darwanto dan Yustikasari, 2007:4) juga menyatakan bahwa 'penerimaan pemerintah hendaknya lebih banyak untuk program-program layanan publik'. Pemda hendaknya dapat lebih menyadari arti penting dari pembangunan yang diwujudkan melalui belanja modal terutama yang berorientasi pada publik mengingat bahwa setiap pengeluaran terhadap pelayanan publik akan memberikan pengembalian bagi daerah. Dan bahwa seharusnya setiap rupiah yang dikeluarkan oleh pemerintah harus dapat menghasilkan nilai tambah bagi perekonomian daerah dan kemakmuran masyarakat yang diindikasikan melalui target yang bersifat kuntitatif (Saragih, 2003:81).

Jurnal Akuntansi Riset, Prodi Akuntansi UPI, Vol. 1, No. 2 
Dalam konteks pengelolaan keuangan daerah, kemampuan pemerintah daerah sangat diperlukan dalam menciptakan alokasi belanja yang efektif, efisien, dan ekonomis sesuai dengan basis anggaran kinerja. Selain itu pemerintah daerah pun harus memperhatikan bahwa kebijakan alokasi yang dibuatnya mampu memberikan manfaat terutama bagi publik. Pernyataan ini sesuai dengan konsep multi-term expenditure framework (MTEF) yang disampaikan oleh Allen dan Tommasi (dalam Halim dan Abdullah, 2006:18) yang menyatakan bahwa kebijakan belanja modal harus memperhatikan kemanfaatan (usefulness) dan kemampuan keuangan pemerintah daerah (budget capability) dalam pengelolaan asset tersebut dalam jangka panjang. Hal ini berarti bahwa dalam pengelolaan asset terkait dengan belanja pemeliharaan, dan sumber pendapatan.

Beberapa hasil penelitian empiris pun telah dilakukan untuk melihat keterkaitan antara belanja modal dengan sumber pendapatan daerah. Hasil penelitian Hariyanto dan Hari Adi (2006) yang menyatakan bahwa ada hubungan positif antara alokasi belanja modal dengan Pendapatan Asli Daerah (PAD) dan Dana Alokasi Umum (DAU). Selain itu hasil penelitian Darwanto dan Yustikasari juga menyatakan hal yang sama yaitu adanya hubungan positif PAD dan DAU dengan alokasi belanja modal. Kedua penelitian tersebut dilakukan pada pemerintah Kabupaten/Kota se-Jawa Bali. Sehingga penyusun ingin mencoba kembali untuk melakukan penelitian tersebut dengan daerah penelitian Kabupaten/Kota di Jawa Barat.

\section{Rumusan Masalah}

Berdasarkan latar belakang, maka dapat dibuat rumusan masalah yaitu bagaimana hubungan PAD dan DAU dengan belanja modal pada Kabupaten/Kota di Jawa Barat pada tahun 2007 baik secara parsial maupun bersama-sama.

\section{Kerangka Pemikiran}

Menurut Undang-Undang Republik Indonesia Nomor 32 Tahun 2004 tentang Pemerintahan Daerah, bahwa yang dimaksud dengan otonomi daerah adalah hak, wewenang, dan kewajiban daerah otonom untuk mengatur dan mengurus sendiri urusan pemerintahan dan kepentingan masyarakat setempat sesuai dengan peraturan perundang-undangan. Otonomi daerah memberikan kewenangan seluas-luasnya kepada daerah untuk mengelola, mengatur, dan mengoptimalkan sumber daya yang dimiliki daerah bagi kepentingan daerah otonom.

Otonomi daerah yang telah dilaksanakan sejak Januari 2001 lalu berdasarkan Undang-Undang No. 22 Tahun 1999 sebagaimana diubah dengan UU No. 32 Tahun 2004 tentang Pemerintahan Daerah serta UU No 25 Tahun 1999 yang diamandemen menjadi UU No. 33 Tahun 2004 yang mengatur mengenai perimbangan keuangan antara pusat dan daerah, telah berimplikasi pada berbagai perubahan pokok yang dirasakan oleh daerah termasuk perubahan penting dalam pengelolaan anggaran daerah (Halim, 2004:221).

Berdasarkan Undang-Undang Nomor 17 tahun 2003 tentang Keuangan Negara disebutkan bahwa Anggaran Pendapatan dan Belanja Daerah (APBD) adalah rencana keuangan tahunan pemerintah daerah yang disetujui oleh Dewan Perwakilan Rakyat Daerah. APBD merupakan wujud pengelolaan keuangan daerah yang ditetapkan Jurnal Akuntansi Riset, Prodi Akuntansi UPI, Vol. 1, No. 2 
setiap tahun dengan Peraturan Daerah. Di dalam APBD ini terkandung banyak kepentingan publik yang menjadikan APBD ini sebagai alat yang sangat penting dalam pengelolaan keuangan daerah. Menurut Mardismo (2002:63) anggaran di dalam sektor publik penting karena beberapa alasan, yaitu :

a. Anggaran merupakan alat bagi pemerintah untuk mengarahkan pembangunan sosial ekonomi, menjamin kesinambungan, dan meningkatkan kualitas hidup masyarakat

b. Anggaran diperlukan karena adanya kebutuhan dan keinginan masyarakat yang tak terbatas dan terus berkembang, sedangkan sumber daya yang ada terbatas. Anggaran diperlukan karena adanya masalah keterbatasan sumaber daya (scarcity of resources), pilihan (choice), dan trade offs.

c. Anggaran diperlukan untuk meyakinkan bahwa pemerintah telah bertanggung jawab terhadap rakyat. Dalam hal ini anggaran publik merupakan instrumen pelaksanaan akuntabilitas publik oleh lembaga-lembaga publik yang ada.

Melihat peranan APBD yang begitu penting terutama untuk meningkatkan kesejahteraan masyarakat melalui pembangunan sosial dan ekonomi, memberikan indikasi bahwa pengelolaaan APBD haruslah dilakukan secara tertib, taat pada peraturan perundang-undangan, efisien, ekonomis, efektif, transparan, dan bertanggungjawab dengan memperhatikan asas keadilan, kepatuhan, dan manfaat untuk masyarakat, seperti yang tertuang dalam Pasal 4 (1) PP No 58 Tahun 2005.

APBD pada hakekatnya mencerminkan bagaimana pemerintah daerah mengelola keuangan daerahnya. APBD ini terdiri atas pendapatan, belanja, dan pembiayaan (Halim,2004). Adapun sumber-sumber pokok keuangan daerah terdiri dari PAD, dana perimbangan yang terdiri dari DAU dan DAK, dan pendapatan lainnya yang sah. Sedangkan untuk pengeluaran diklasifikasikan menurut organisasi, fungsi dan jenis belanja.

Halim (2002:64) menyatakan bahwa "Pendapatan Asli Daerah (PAD) merupakan semua penerimaan daerah yang berasal dari sumber ekonomi asli daerah." Pendapatan Asli Daerah ini dipisahkan menjadi pajak daerah, retribusi daerah, bagian laba usaha daerah, dan lain-lain PAD yang sah. Sedangkan Dana Alokasi Umum (DAU) merupakan dana yang berasal dari APBD yang dialokasikan dengan tujuan pemerataan kemampuan keuangan antar daerah untuk membiayai kebutuhan pengeluaran dalam rangka pelaksanaan desentralisasi. (Yani, 2004:110). Kedua sumber penerimaan ini memiliki karakteristik yang sama yaitu perannya dalam membiayai pelaksanaan otonomi daerah guna mencapai tujuan utama penyelenggaraan otonomi daerah yang ingin meningkatkan pelayanan publik dan memajukan perekonomian daerah (Mardiasmo, 2002:46), yang realisasinya dapat diterapkan pada pengalokasian belanja modal guna meningkatkan pelayanan pada masyarakat sehingga masyarakat dapat menjadi produktif dan nantinya dapat kembali meningkatkan penerimaan daerah.

Halim (2002:72) mendefinisikan belanja modal sebagai berikut :

Belanja modal adalah pengeluaran pemerintah daerah yang manfaatnya melebihi satu tahun anggaran dan akan menambah asset atau kekayaan daerah dan selanjutnya akan menambah biaya rutin seperti biaya operasi dan pemeliharaan. Belanja modal terbagi dua, yaitu 1) Belanja publik, yaitu belanja yang manfaatnya dapat dinikmati secara 
langsung oleh masyarakat umum. Seperti pembangunan jembatan dan jalan raya, pembelian alat transportasi massa, dan pembelian mobil ambulans. 2) Belanja aparatur, yaitu belanja yang manfaatnya tidak secara langsung dinikmati oleh masyarakat, tetapi dirasakan secara langsung oleh aparatur. Seperti pembelian kendaraan dinas, pembangunan gedung pemerintahan, dan pembangunan rumah dinas.

Belanja modal dimaksudkan untuk mendapatkan asset tetap pemerintah, yakni peralatan, pembangunan, infrastruktur, dan harta tetap lainnya (Abdullah dan Halim, 2006:19) baik bagi kepentingan publik maupun aparatur sendiri. Sebab seperti yang telah diungkapkan Halim (2002:72) bahwa belanja modal yang dilakukan oleh pemerintah daerah terbagi menjadi belanja publik dan belanja aparatur. Akan tetapi dalam rangka peningkatan pelayanan publik, maka akan lebih bijak apabila pemda lebih mengutamakan belanja modal yang bersifat publik. Belanja ini dapat berupa pembangunan dan perbaikan pada sektor-sektor yang memang sangat diperlukan daerah atau dengan kata lain pemerintah daerah harus melakukan skala prioritas dalam penentuan belanja modal seperti memprioritaskan sektor pendidikan, kesehatan, transportasi yang dapat menstimulus produktivitas perekonomian baik dalam jangka pendek maupun untuk masa depan, sehingga pada akhirnya dapat berdampak pada peningkatan pendapatan daerah. Dan jikapun Pemda akan melakukan belanja modal bagi aparatur, maka haruslah untuk meningkatkan kinerja dalam rangka pelayanan publik. Atau dengan kata lain, bahwa tujuan akhirnya adalah untuk pelayanan publik.

Harianto dan Hari Adi (2006:5) menyebutkan bahwa tersedianya infrastruktur yang baik diharapkan dapat menciptakan efisiensi dan efektifitas di berbagai sektor, produktifitas masyarakat diharapkan menjadi semakin tinggi dan pada gilirannya terjadi peningkatan pertumbuhan ekonomi. Siagian (2003) menyatakan bahwa pada gilirannya pembangunan ekonomi yang berhasil akan berakibat positif pada kehidupan bermasyarakat, berbangsa, dan bernegara.

Akan tetapi pemerintah daerah juga harus mempertimbangkan mengenai kemampuan daerah dalam menentukan alokasi belanja sehingga diperlukan sikap efisiensi anggaran di setiap penyusunan anggaran. Apalagi dengan berdasar pada teori bahwa asset merupakan pembatasan asset, yang tidak dapat semena-mena untuk dialokasikan. Pada intinya pemerintah daerah harus dapat memanfaatkan uang sebaik mungkin agar dapat menghasilkan perbaikan pelayanan kesejahteraan yang maksimal guna kepentingan masyarakat (Sum dalam Halim, 2004:259). Hal ini didukung pula oleh Pamuji (dalam Kaho, 2005:138) bahwa 'Pemda tidak akan dapat melaksanakan fungsinya dengan efektif dan efisien tanpa biaya yang cukup untuk memberikan pelayanan dan pembangunan...' Sehingga, menurut Kaho (2005:138) untuk memiliki keuangan yang memadai dengan sendirinya daerah membutuhkan sumber keuangan yang cukup pula, dalam hal ini daerah dapat memperolehnya dengan beberapa cara :

1) Ia dapat mengumpulkan dana dari pajak daerah yang sudah direstui Pemerintah pusat. 2) Pemda dapat melakukan pinjaman dari pihak ketiga, pasar uang atau bank atau melalui pemerintah pusat. 3) ikut ambil bagian dalam pendapatan pajak sentral yang dipungut daerah, misalnya sekian persen dari pendapatan sentral tersebut. 4) Pemda dapat menambah tarif pajak sentral tertentu, seperti pajak kekayaan atau pajak pendapatan. 5) Pemda dapat menerima bantuan atau subsidi dari pemerintah pusat. 
Selama ini alokasi belanja modal dipenuhi melalui penerimaan dalam APBD. Dalam pasal 155 ayat 1 UU No 32 tahun 2004 dijelaskan bahwa "penyelenggaraan tugas pemerintahan yang menjadi kewenangan daerah didanai dari dan atas beban anggaran pendapatan dan belanja daerah." Sejalan dengan hal tersebut, Mardiasmo (2002:135) menyatakan bahwa untuk membiayai pelaksanaan asas desentralisasi maka pembiayaan kegiatan-kegiatan tersebut bersumber dari APBD. Sumber-sumber pokok keuangan tersebut bersumber dari PAD dan dana perimbangan yang terdiri dari DAU dan DAK.

PAD sebenarnya merupakan andalan utama daerah untuk mendukung penyelenggaraan pemerintahan dan pembiayaan pembangunan (Saragih, 2003:55). Tetapi penerimaan daerah dari unsur PAD saja belum mampu memenuhi kebutuhan daerah apalagi dengan penambahan wewenang daerah jelas akan membutuhkan dana tambahan daerah (Saragih, 2003:49), sehingga daerah masih tetap membutuhkan bantuan atau dana yang berasal dari pusat. Dengan begitu maka secara langsung terdapat hubungan antara penerimaan daerah melalui PAD dan DAU dengan alokasi belanja modal untuk membiayai kegiatan pemerintah dalam rangka pelaksanaan desentralisasi.

Studi mengenai hubungan antara PAD dan DAU dengan alokasi belanja modal sebenarnya telah banyak dilakukan melalui kajian secara empiris. Penelitian Abdullah dan Halim (2006) menyebutkan bahwa sumber pendapatan daerah berupa PAD dan dana perimbangan berpengaruh terhadap belanja daerah secara keseluruhan. Meskipun proporsi PAD maksimal hanya $10 \%$ dari total pendapatan daerah, kontribusinya cukup besar terhadap pengalokasian anggaran (Abdullah dan Halim, 2006:19). Lalu di dalam lampiran PP No 24 tahun 2005 tersirat bahwa pada dasarnya sebagian besar pendapatan pemerintah bersumber dari pungutan pajak dalam rangka memberikan pelayanan kepada masyarakat. Dengan begitu maka PAD memiliki hubungan dengan pengalokasian belanja modal terkait dengan pembiayaan pembangunan daerah.

Seperti PAD, maka DAU juga memiliki hubungan dengan alokasi belanja modal. Holtz-Eakin et al (dalam Hariyanto dan Hari Adi, 2006) menyatakan bahwa terdapat keterkaitan sangat erat antara transfer dari pemerintah pusat dengan belanja modal. Kemudian Gamkhar dan Oates (dalam Maimunah, 2006:5) menyatakan bahwa pengurangan jumlah transfer (cut in the federal grants) menyebabkan penurunan dalam pengeluaran daerah. Hal ini mengindikasikan bahwa terdapat hubungan antara pemberian dana transfer dari pemerintah pusat yaitu DAU, dengan alokasi pengeluaran daerah melalui alokasi belanja modal. Saragih (2003:57) pun mengemukakan bahwa pengalaman empiris menunjukkan bahwa sebagian besar daerah tidak mampu mengandalkan PAD untuk membiayai kebutuhan pengeluarannya, sehingga harus mendapatkan dana dari pusat berupa DAU untuk membiayai pengeluaran daerah.

Hasil penelitian yang telah dilakukan pun menunjukkan bagaimana hubungan PAD dan DAU dengan belanja modal. Seperti hasil penelitian Hariyanto dan Hari Adi (2006) dan Darwanto dan Yustikasari (2007) yang menyatakan bahwa ada hubungan positif antara alokasi belanja modal dengan PAD dan DAU. 


\section{METODE PENELITIAN}

Penelitian ini merupakan penelitian kuantitatif, dengan menggunakan metode verifikatif atau penelitian yang ditinjau dari tujuan. Adapun tujuan penelitian ini adalah untuk meneliti kembali penelitian yang telah dilakukan sebelumnya. Untuk mencapai tujuan tersebut, maka dilakukan pengumpulan data sekunder melalui teknik telaah dokumen.

Teknik sampel yang digunakan adalah nonprobability sampling, sampling jenuh Pada penelitian ini, semua anggota populasi yang akan dijadikan sampel adalah LRA 25 Kabupaten/Kota Di Jawa Barat pada Tahun Anggaran (TA) 2007. Sebenarnya pada tahun 2007, Jawa Barat telah memiliki $26 \mathrm{Kab} / \mathrm{Kota}$, akan tetapi karena kabupaten terakhir yaitu Kab. Bandung Barat baru didirikan pada 2007 maka belum termasuk ke dalam populasi ini. Pemilihan TA 2007 dilakukan karena pada tahun tersebut sudah mulai dilaksanakannya Permendagri Nomor 13 Tahun 2006 tentang pedoman pengelolaan keuangan daerah yang kini diubah menjadi Permendagri Nomor 59 Tahun 2007

Variabel independen dalam penelitian ini adalah PAD dan DAU yang diukur dari jumlah realisasi PAD dan DAU TA 2007. Sedangkan variabel dependen adalah belanja modal yang diukur dari realisasi belanja modal TA 2007.

Penelitian ini menggunakan teknik statistik deskriptif karena tidak memerlukan penggeneralisasian. Adapun teknik statistik yang digunakan adalah korelasi product momen pearson untuk menghitung hubungan PAD dan DAU dengan belanja modal secara individual. Dan korelasi berganda untuk menghitung hubungan PAD dan DAU dengan belanja modal secara bersama-sama.

\section{Hasil Penelitian}

\section{Hubungan PAD dengan belanja modal}

Untuk menghitung besarnya korelasi antara PAD dengan belanja modal secara lebih jelas maka digunakan rumus analisis korelasi linier product momen pearson

Hasil pengolahan data pada tabel menunjukkan koefisien korelasi linier PAD dengan alokasi belanja modal sebesar 0.612 . Berdasarkan kriteria pengujian hipotesis bahwa hipotesis penelitian diterima jika koefisien korelasi $(\rho) \geq 0.60$ dan jika koefisien korelasi $(\rho) \leq 0.60$ maka hipotesis penelitian ditolak. Pada penelitian ini, karena koefisien korelasi menunjukkan nilai 0.612 maka hipotesis penelitian diterima, artinya terdapat hubungan positif yang kuat antara PAD dengan belanja modal di Kabupaten dan Kota di Jawa Barat pada tahun 2007.

Koefisien Korelasi Linier Sederhana

\begin{tabular}{|c|c|c|c|c|}
\hline & & PAD & DAU & B.MODAL \\
\hline \multirow[t]{3}{*}{ PAD } & Pearson Correlation & 1 & $.431\left(^{*}\right)$ & $.612\left(^{* *}\right)$ \\
\hline & Sig. (2-tailed) & & .032 & .001 \\
\hline & $\mathbf{N}$ & 25 & 25 & 25 \\
\hline \multirow[t]{3}{*}{ DAU } & Pearson Correlation & $.431\left(^{*}\right)$ & 1 & $.630(* *)$ \\
\hline & Sig. (2-tailed) & .032 & & .001 \\
\hline & $\mathrm{N}$ & 25 & 25 & 25 \\
\hline \multirow[t]{3}{*}{ B.MODAL } & Pearson Correlation & $.612\left(^{* *}\right)$ & $.630(* \#)$ & 1 \\
\hline & Sig. (2-tailed) & .001 & .001 & \\
\hline & $\mathbf{N}$ & 25 & 25 & 25 \\
\hline
\end{tabular}

Jurnal Akuntansi Riset, Prodi Akuntansi UPI, Vol. 1, No. 2 


\section{Hubungan DAU dengan belanja modal}

Untuk menghitung besarnya korelasi antara PAD dengan belanja modal dengan lebih jelas maka digunakan rumus analisis korelasi linier product momen pearson, Pada tabel tersebut diketahui bahwa besarnya koefisen korelasi antara DAU dan belanja modal adalah sebesar 0.630 , yang berarti bahwa hipotesis penelitian ini diterima, yaitu terdapat hubungan positif yang kuat antara DAU dengan alokasi belanja modal.

\section{Hubungan PAD dan DAU dengan belanja modal}

Koefisien Korelasi Berganda

\begin{tabular}{|l|c|c|r|r|r|r|r|r|r|}
\hline Model & $\mathrm{R}$ & R Square & $\begin{array}{c}\text { Adjusted R } \\
\text { Square }\end{array}$ & $\begin{array}{c}\text { Std. Error } \\
\text { of the } \\
\text { Estimate }\end{array}$ & \multicolumn{5}{|c|}{ Change Statistiks } \\
\hline & & & & $\begin{array}{r}\text { R Square } \\
\text { Change }\end{array}$ & F Change & df1 & df2 & $\begin{array}{c}\text { Sig. F } \\
\text { Change }\end{array}$ \\
\hline 1 & & & .497 & $\begin{array}{r}67028858 \\
931.5284 \\
0\end{array}$ & .539 & 12.850 & 2 & 22 & .000 \\
\hline
\end{tabular}

Hasil pengolahan data pada tabel di atas menunjukkan bahwa koefisien korelasi berganda antara PAD dan DAU dengan alokasi belanja modal adalah 0.734. Berdasarkan kriteria pengujian hipotesis bahwa hipotesis penelitian diterima jika koefisien korelasi $(\rho) \geq 0.60$ dan jika koefisien korelasi $(\rho) \leq 0.60$ maka hipotesis penelitian ditolak. Pada penelitian ini, karena koefisien korelasi berganda menunjukkan nilai 0.734 maka hipotesis penelitian diterima, artinya terdapat hubungan positif yang kuat antara PAD dan DAU dengan belanja modal di Kabupaten dan Kota di Jawa Barat pada tahun 2007.

\section{Pembahasan}

\section{Hubungan PAD dengan Belanja Modal}

Selama ini PAD memiliki peran untuk membiayai pelaksanaan otonomi daerah guna mencapai tujuan utama penyelenggaraan otonomi daerah yang ingin meningkatkan pelayanan publik dan memajukan perekonomian daerah (Mardiasmo, 2002:46). Bermula dari keinginan untuk mewujudkan harapan tersebut, Pemda melakukan berbagai cara dalam meningkatkan pelayanan publik, yang salah satunya dilakukan dengan melakukan belanja untuk kepentingan investasi yang direalisasikan melalui belanja modal.

Pada penelitian ini memberikan hasil bahwa terdapat hubungan positif yang kuat antara PAD dengan belanja modal. Hasil penelitian ini serupa dengan hasil penelitian Daryanto dan Yustikasari (2007) yang menyatakan bahwa terdapat hubungan positif dan signifikan antara PAD dengan belanja modal. Hal ini dapat diartikan bahwa semakin tinggi PAD maka pengeluaran pemerintah atas belanja modal pun akan semakin tinggi. Selain itu, temuan tersebut juga mengindikasikan bahwa besarnya PAD menjadi salah satu faktor penentu dalam menetukan belanja modal. Hal ini sesuai dengan PP No 58 tahun 2005 tentang pengelolaan keuangan daerah yang menyatakan bahwa APBD disusun sesuai dengan kebutuhan penyelenggaraan pemerintahan dan Jurnal Akuntansi Riset, Prodi Akuntansi UPI, Vol. 1, No. 2 
kemampuan pendapatan daerah. Artinya, disetiap penyusunan APBD, jika Pemda akan mengalokasikan belanja modal maka harus benar-benar disesuaikan dengan kebutuhan daerah dengan mempertimbangkan PAD yang diterima. Besar kecilnya belanja modal akan ditentukan dari besar kecilnya PAD. Sehingga jika Pemda ingin meningkatkan pelayanan publik dan kesejahteraan masyarakat dengan jalan meningkatkan belanja modal, maka Pemda harus berusaha keras untuk menggali PAD yang sebesar-besarnya.

\section{Hubungan DAU dengan Belanja Modal}

PAD sebenarnya merupakan andalan utama daerah untuk mendukung penyelenggaraan pemerintahan dan pembiayaan pembangunan (Saragih, 2003:55). Tetapi penerimaan daerah dari unsur PAD saja belum mampu memenuhi kebutuhan daerah apalagi dengan penambahan wewenang daerah jelas akan membutuhkan dana tambahan bagi daerah (Saragih, 2003:49) sehingga daerah masih tetap membutuhkan bantuan atau dana yang berasal dari pusat. Bantuan pusat ini biasa disebut dengan Dana Alokasi Umum (DAU).

Hasil penelitian menunjukkan bahwa DAU memiliki hubungan positif yang kuat dengan belanja modal. Hal ini dapat diartikan bahwa semakin tinggi DAU yang diterima daerah maka akan semakin tinggi pula belanja modal yang akan dibelanjakan. Hasil penelitian ini serupa dengan penelitian Daryanto dan Yustikasari (2007) yang menyatakan bahwa terdapat hubungan positif dan signifikan antara DAU dengan belanja modal. Holtz-Eakin et al (dalam Hariyanto dan Hari Adi, 2005) pun menyatakan bahwa terdapat keterkaitan sangat erat antara transfer dari pemerintah pusat dengan belanja modal. Kemudian Gamkhar dan Oates (dalam Maimunah, 2006:5) juga menyatakan bahwa pengurangan jumlah transfer (cut in the federal grants) menyebabkan penurunan dalam pengeluaran daerah. Hal ini mengindikasikan bahwa terdapat hubungan antara pemberian dana transfer dari pemerintah pusat yaitu DAU, dengan alokasi pengeluaran daerah melalui alokasi belanja modal.

Hubungan positif yang kuat antara DAU dengan belanja modal ini dapat dipahami mengingat bahwa pelaksanaan otonomi daerah yang bertujuan untuk meningkatkan pelayanan publik -yang direalisasikan melalui belanja modal- juga ikut dibiayai oleh DAU tersebut. Bahkan Abdullah dan Halim (2006:26) menyatakan bahwa. pendapatan dari pemerintah pusat berupa dana perimbangan di pemerintah daerah di Indonesia merupakan sumber pendapatan utama dalam APBD. Sayangnya kontribusi DAU terhadap belanja modal masih belum efektif sehingga masih banyak daerah yang belum merata pembangunannya, juga masih kurangnya pelayanan publik sehingga kesejahteraan masyarakat pun belum efektif (masih banyaknya masyarakat dibawah garis kemiskinan, belum meratanya fasilitas pendidikan dan kesehatan, sektor usaha kecil masih terabaikan -contoh PKL).

\section{Hubungan PAD dan DAU dengan Belanja Modal}

PAD dan DAU merupakan sumber pendapatan daerah yang memiliki peran utama dalam pelaksanaan otonomi daerah dalam rangka mencapai tujuan utama penyelenggaraan otonomi daerah yang ingin meningkatkan pelayanan publik dan memajukan perekonomian daerah (Mardiasmo, 2002:46). Berdasarkan penelitian dapat diketahui bahwa PAD dan DAU memiliki hubungan positif yang kuat dengan belanja 
modal. Hal ini dapat diartikan bahwa semakin tinggi PAD dan DAU yang didapat daerah maka akan semakin tinggi pula belanja modal yang dikeluarkan daerah.

Kedua sumber pendapatan daerah ini memang sulit untuk dipisahkan. Pemerintah daerah belum mampu mengandalkan PAD-nya sendiri untuk membiayai desentralisasi. Begitu pun dengan pemerintah pusat yang tidak mau sepenuhnya memberikan DAU karena akan menambah ketergantungan daerah kepada pusat.

Kombinasi kedua sumber pendapatan ini -jika melihat kepada hasil penelitian- maka akan menghasilkan pendapatan yang lebih besar bagi daerah guna meningkatkan belanja modal. Semakin tinggi PAD disertai dengan semakin meningkatnya DAU akan meningkatkan belanja modal daerah. Sebab daerah akan memiliki pendapatan yang besar sehingga belanja pun dapat ikut ditingkatkan. Meskipun pada kenyataannya peningkatan PAD tidak selalu diikuti dengan peningkatan DAU, sebab melihat bahwa penentuan DAU ikut ditentukan pula oleh besarnya PAD (PP No 55 tahun 2005 tentang dana perimbangan).

\section{Simpulan}

a. Hasil penelitian mengenai hubungan PAD dengan belanja modal menunjukkan koefisien korelasi sebesar 0.612 . Hal ini berarti hipotesis diterima yaitu terdapat hubungan positif yang kuat antara PAD dengan belanja modal.

b. Hasil penelitian mengenai hubungan DAU dengan belanja modal menunjukkan koefisien korelasi sebesar 0.630 . Hal ini juga berarti hipotesis penelitian diterima yaitu terdapat hubungan positif yang kuat antara DAU dengan belanja modal.

c. Berdasarkan penelitian mengenai hubungan PAD dan DAU dengan belanja modal dapat diketahui bahwa koefisien korelasi berganda adalah 0.734 . Hal ini berarti hipotesis penelitian diterima yaitu bahwa PAD dan DAU memiliki hubungan positif yang kuat dengan belanja modal.

Saran

a. Sebaiknya Pemda memprioritaskan anggaran untuk kepentingan publik dengan cara meningkatkan alokasi belanja modal untuk kepentingan public

b. Sebaiknya Pemda terus meningkatkan PAD dibandingkan dengan DAU, sebab PAD merupakan tolak ukur kemandirian daerah. Salah satu cara meningkatkan PAD dapat dilakukan melalui ekstensifikasi dan intensifikasi pajak. Dengan tingginya PAD tersebut maka akan semakin mengurangi ketergantungan pemerintah daerah terhadap bantuan pusat.

c. Diharapkan akan ada penelitian lanjutan terutama untuk meneliti mengenai bagaimana hubungan ataupun pengaruh dari tingginya belanja modal terhadap aspek lainnya (bisa terhadap pendapatan daerah maupun belanja lainnya), dengan menggunakan rentang data yang lebih lama sehingga dapat diketahui peningkatan maupun penurunannya. 
Daftar Pustaka

Abdul, Halim. (2004). Bunga Rampai Manajemen Keuangan Daerah. Jogjakarta: UPP AMP YKPN

Abdul, Halim. (2006). Bunga Rampai Pengelolaan Keuangan Daerah. Jogjakarta: UPP AMP YKPN

Abdul, Halim. (2002). Akuntansi Keuangan Daerah. Jakarta: Salemba Empat

Abdullah, Sukriy dan Abdul Halim. (2006). ${ }^{6 S t u d i}$ atas Belanja Modal pada Anggaran Pemerintah Daerah dalam Hubungannya dengan Belanja Pemeliharaan dan Sumber Pendapatan". Jurnal Akuntansi Pemerintah. Vol.2 No.2 Hal 17-32

Arikunto, Suharsimi. (1996). Prosedur Penelitian-Suatu Pendekatan Praktek-. Jakarta: PT. Rineka Cipta

Badan Pemeriksa Keuangan. (2007). Laporan Hasil Pemeriksaan Laporan Keuangan TA 2007. Bandung: Perwakilan BPK RI

Darwanto, dan Yustikasari. (2007). "Pengaruh Pertumbuhan Ekonomi, Pendapatan Asli Daerah, dan Dana Alokasi Umum terhadap Pengalokasian Anggaran Belanja Modal". Simposium Nasional Akuntansi. Juli. Makasar

Editorial Media Indonesia. Menggenjot Belanja Modal. Edisi 25 Agustus 2008. [Online]. Tersedia: http://www.media-indonesia.com. Html [26 April 2009]

Hariyato, dan Priyo Hari Adi. (2006). "Hubungan antara Dana Alokasi Umum, Belanja Modal, Pendapatan Asli Daerah, dan Pendapatan Per Kapita”. Skripsi. Salatiga: Fakultas Ekonomi Universitas Kristen Satya Wacana

Hasan, Iqbal. (2003). Pokok-Pokok Materi Statistika 1 (Statistik Deskriptif). Jakarta: PT Bumi Aksara

Indriantoro, Nur.,dan Bambang Supomo. (2002). Metodologi Penelitian Bisnis. Yogyakarta: Penerbit BPFE

Kaho, Josef Riwu. (2005). Prospek Otonomi Daerah. Jakarta: Raja Grafindo Persada

Mardiasmo. (2002). Otonomi dan Manajaemen Keuangan Daerah. Yogyakarta: Penerbit ANDI

Mardiasmo (2004). Akuntansi Sektor Publik. Yogyakarta: Penerbii ANDI

Moch. Nazir. (2003). Metode Penelition. Jakarta: Ghalia Indonesia

Mutiara, Maimunah. (2006). 'Flypaper Effect pada Dana Alokasi Umum (DAU) dan Pendapatan Asli Daerah (PAD) terhadap Belanja Daerah pada Kabupaten/Kota di Pulau Sumatera". Simposium Nasional Akuntansi. Agustus. Padang

Saragih, Juli Panglima. (2003). Desentralisasi Fiskal dan Keuangan Daerah dalam Otonomi. Jakarta: Ghalia Indonesia

Pemprov Jawa Barat. (2009). Sekilas Jabar. [Online]. Tersedia: http://www.jabarprov.go.id. Html [10 Juni 2009]

Siagian, Sondang P. (2003). Administrasi Pembangunan (Konsep, Dimensi dan Strateginya). Jakarta: PT Bumi Aksara

Sudjana. (1996). Statistika Untuk Ekonomi dan Niaga I. Bandung: Tarsito (1997). Statistika Untuk Ekonomi dan Niaga II. Bandung: Tarsito

Sugiyono. (2002). Metode Penelitian Bisnis. Bandung: Penerbit CV Alfabeta

Sugiyono. (2000). Statistik Untuk Penelitian. Bandung: Penerbit CV Alfabeta

Umar, Husein. (2004). Metode Penelitian Untuk Skripsi dan Tesis Bisnis. Jakarta: PT Raja Grafindo Persada

Jurnal Akuntansi Riset, Prodi Akuntansi UPI, Vol. 1, No. 2 
Waluyo. dan Wirawan B Ilyas. (2003). Perpajakan Indonesia. Jakarta: Salemba Empat Yani, Ahmad. (2004). Hubungan Keuangan Antara Pemerintah Pusat dan Daerah di Indonesia. Jakarta: PT Raja Grafindo Persada

\section{Peraturan-Peraturan}

Undang-Undang No. 17 Tahun 2003 Tentang Keuangan Negara

Undang-Undang No. 32 Tahun 2004 Tentang Pemerintahan Daerah

Undang-Undang No. 33 Tahun 2004 Tentang Perimbangan Keuangan Antara Pusat Dan Daerah

Undang-Undang No. 34 Tahun 2000 Tentang Pajak Daerah dan Retribusi Daerah

PP No. 24 Tahun 2005 tentang Standar Akuntansi Pemerintahan

PP No. 55 Tahun 2005 tentang Dana Perimbangan

PP No. 58 Tahun 2005 tentang Pengelolaan Keuangan Daerah

Perpres No. 104 tahun 2006 tentang DAU Provinsi, Kabupaten, dan Kota Tahun Tahun 2007

Permendagri No. 13 Tahun 2006 tentang Pedoman Pengelolaan Keuangan Daerah yang telah diubah menjadi Permendagri No. 59 Tahun 2007 